ISSN: 2302-8556

\title{
Pengaruh Tax Avoidance terhadap Nilai Perusahaan dengan Kebijakan Dividen sebagai Variabel Moderasi
}

\author{
Lina Apsari ${ }^{1}$ \\ Putu Ery Setiawan ${ }^{2}$ \\ ${ }^{1}$ Fakultas Ekonomi dan Bisnis Universitas Udayana (Unud), Bali, Indonesia \\ email: linaapsari2@gmail.com/ Tlp: +6281238307459 \\ ${ }^{2}$ Fakultas Ekonomi dan Bisnis Universitas Udayana (Unud), Bali, Indonesia
}

\begin{abstract}
ABSTRAK
Tax avoidance dapat meningkatkan nilai perusahaan atau menurunkan nilai perusahaan. Penelitian ini bertujuan untuk mengetahui pengaruh tax avoidance terhadap nilai perusahaan dengan kebijakan dividen sebagai variabel moderasi.Penelitian dilakukan pada perusahaan manufaktur sektor industri barang konsumsi yang terdaftar di Bursa Efek Indonesia tahun 2014-2016. Sampel yang diperoleh sebanyak 39 perusahaan dengan metode nonprobability sampling, khususnya purposive sampling. Teknik analisis data yang digunakan adalah Moderated Regression Analysis (MRA). Hasil analisis menemukan bahwa ETR berpengaruh positif pada nilai perusahaan. Nilai ETR yang rendah mengindikasikan adanya aktivitas tax avoidance yang tinggi dan menurunkan nilai perusahaan. Hal ini dikarenakan bagi perusahaan aktivitas tax avoidance menyebabkan perusahaan dinilai buruk. Kebijakan dividen dalam penelitian ini mampu memperlemah pengaruh negatif tax avoidance pada nilai perusahaan. Hal ini dikarenakan bagi investor pembayaran dividen meningkatkan kesejahteraan investor dan mampu menarik investor baru untuk berinvestasi di perusahaan tersebut sehingga meningkatkan nilai perusahaan.

Kata kunci:tax avoidance, kebijakan dividen, nilai perusahaan.
\end{abstract}

\begin{abstract}
Tax avoidance can increase company value or decrease firm value. This study aims to determine the effect of tax avoidance on firm value with dividend policy as a moderating variable. The research was conducted at consumer goods sector listed on BEI year 20142016. The samples obtained are 39 companies with nonprobability sampling method, especially purposive sampling. Data analysis used is Moderated Regression Analysis (MRA). The results is ETR has a positive effect on firm value. Low ETR values indicate high tax avoidance activity and lower firm value. This is because tax avoidance activities cause the company is considered poor. The dividend policy able to weaken the negative effect of tax avoidance on firm value. This is because for investors paying dividends increase the welfare of investors and able to attract new investors to invest in the company thus increasing the firm value.

Keywords: tax avoidance, dividend policy, firm value.
\end{abstract}

\section{PENDAHULUAN}

Salah satu tujuan perusahaan adalah mempertahankan eksistensi perusahaan diantara ketatnya persaingan. Eksistensi perusahaan dapat dipertahankan dengan adanya peningkatan nilai perusahaan tiap periode yang akan memengaruhi 
kesejahteraan para investor. Hal ini dapat membuat investor lain tertarik untuk berinvestasi di perusahaan tersebut. Tingkat kemakmuran investor yang tinggi menarik investor lain untuk berinvestasi di perusahaan berimplikasi pada peningkatan nilai perusahaan. Dalam hal meningkatkan nilai perusahaan terdapat kendala-kendala yang dihadapi seperti kewajiban membayar pajak.

Pajak merupakan pengenaan tarif terhadap penghasilan yang diperoleh orang pribadi atau badan berdasarkan undang-undang oleh pemerintah. Bagi pengenaan pajak terhadap penghasilan dianggap sebagai beban dalam menjalankan operasional perusahaan. Pajak sebagai biaya akan menurunkan besarnya laba yang diperoleh perusahaan. Sehingga manajer akan melakukan upaya untuk menekan jumlah pajak yang dibayar untuk meningkatkan besarnya laba. Perbedaan pandangan antara perusahaan dan pemerintah terhadap perpajakan memotivasi manajemen melakukan beberapa cara, salah satunya manajemen pajak. Menurut Suandy (2011), manajemen pajak merupakan suatu strategidalam meminimalkan pembayaran pajak yang masih dalam batas ketentuan peraturan perundang-undangan. Manajemen pajak yang dilakukan perusahaan dapat meminimalisir beban yang dibayarkan sehingga meningkatkan laba perusahaan. Laba perusahaan yang meningkat diharapkan menjadi sinyal positif bagi investor sehingga meningkatkan nilai perusahaan.

Manajemen pajak dapat dilakukan dengan cara penghindaran pajak serta penggelapan pajak. Penghindaran pajak dan penggelapan pajak merupakan dua cara manajemen pajak yang sulit dibedakan. Menurut Zain (2008), berpedoman dari peraturan undang-undang, batas diantara keduanya ialah, antara melanggar 
undang-undang dan tidak melanggar undang-undang. Berdasarkan penjelasan tersebut penghindaran pajak yang dilakukan perusahaan merupakan upaya yang diperbolehkan karena hanya memanfaatkan hal-hal yang tidak diatur dalam undang-undang.

Menurut Pradnyana (2017), pihak perusahaan sebaiknya merumuskan perencanaan pajak dengan lebih hati-hati. Hal ini dilakukan untuk menghindari tindakan penghindaran pajak yang dilakukan perusahaan tidak termasuk dalam penggelapan pajak, yang mana itu termasuk dalam tindak pidana fiskal. Beberapa penelitian. menggunakan istilah berbeda terhadap aktivitas ini, seperti agresivitas pajak (Frank et al., 2009), manajemen pajak (Minnick and Noga, 2010), dan perencanan pajak (Amstrong et al., 2012). Menurut Gunawan, yang dikutip oleh Lumbantoruan (Lumbantoruan: 1996:485), tax planning merupakan upaya yang diperbolehkan untuk dilakukan oleh wajib pajak. Salah satu strategi tax planning adalah tax avoidance. Tindakan tax avoidance itu diperbolehkan karena penghematan pajak hanya dilakukan dengan memanfaatkan. hal-hal. yang tidak diatur (loopholes).

Upayatax avoidance yang dilakukan perusahaan dapat meningkatkan atau menurunkan nilai perusahaan. Tax avoidance merupakan upaya perusahaan dalam meminimalkan pembayaran pajak sehingga meningkatkan besarnya laba perusahaan.Tax avoidance merupakan upaya perusahaan dalam meminimalkan pembayaran pajak sehingga meningkatkan besarnya laba perusahaan. Hoque et al., (2011) menyatakan tax avoidance dapat dilakukan dengan membebankan biaya personal menjadi biaya operasional untuk menurunkan laba. Prasetyo 
(2013) menyatakan nilai perusahaan menggambarkan tingkat kepercayaan investor pada suatu perusahaan, semakin tinggi nilai perusahaan menggambarkan pemegang saham yang makmur sedangkan nilai perusahaan yang rendah menyebabkan perusahaan dianggap memiliki kinerja buruk sehingga investor enggan berinvestasi di perusahaan tersebut Pada kenyataannya aktivitas tax avoidance dapat menurunkan nilai perusahaan karena perusahaan menyajikan informasi keuangan yang tidak sesungguhnya sehingga menghilangkan kepercayaan investor pada perusahaan tersebut.

Teori tradisional menyebutkan tax avoidance sebagai kegiatanpemindahan kekayaan dari pemerintah kepada pemegang saham (Kim et al., 2010). Dalam upaya peningkatan nilai perusahaan melalui aktivitas tax avoidancememungkinkan manajemen dihadapkan pada konflik agency yaitu konflik kepentingan antara manajer dengan pemegang saham, dimana masingmasing pihak hanya memikirkan keuntungan dirinya sendiri.

Penelitian dari Hanlon dan Slemrod (2009) dan Wahab et al. (2012) mengemukakan perencanaan pajak berpengaruh negatif terhadap nilai perusahaan. Hal ini menunjukkan manajer perusahaan memiliki sifat oportunistik terhadap aktivitas perencanaan pajak sehingga mengakibatkan penurunan nilai perusahaan. Ilmiani dan Sutrisno (2014) serta Ningtias (2015) memperoleh hasil tax avoidance memiliki pengaruh negatif signifikan terhadap nilai perusahaan.

Hasil penelitian Desai dan Dharmapala (2005) memperoleh hasil yang berbeda dimana tax avoidance memiliki pengaruh positif terhadap nilai perusahaan pada perusahaan yang memilki corporate governance yang baik. 
Penelitian yang dilakukan Herdiyanto dan Ardiyanto (2015) juga menunjukkan bahwa tax avoidance berpengaruh positif terhadap nilai perusahaan. Hasil penelitian ini menunjukkan tindakan tax avoidance yang dilakukan perusahaan mampu meningkatkan nilai perusahaan. Tax avoidance yang dilakukan perusahaan untuk meminimalisir beban perusahaan dapat meningkatkan laba perusahaan yang menunjukkan perusahaan memiliki kinerja yang baik sehingga meningkatkan nilai perusahaan.

Kebijakan dividen ialah keputusan keuangan perusahaan apakah laba yang diperoleh akan dibagikan sebagai dividen atau ditahan sebagai laba ditahan (Putra dan Lestari, 2016). Menurut Sugiarto (2011), kebijakan dividen kerapmenyebabkan konflik antara manajer dengan pihak pemegang saham. Hal ini dikarenakan adanya perbedaan kepentingan diantara kedua belah pihak. Apabila laba yang diperoleh dengan melakukan tax avoidance dibagikan kepada investor maka akan meningkatkan nilai perusahaan karenaharga saham suatu perusahaan yang mengalami pertumbuhan konstan menunjukkan bahwa pembayaran dividen yang lebih besar cenderung akan meningkatkan nilai saham. Meningkatnya tingkat pembayaran dividen menunjukkan tingkat kesejahteraan investor yang juga mengindikasikan perusahaan memiliki kinerja yang baik.

Bird in the hand theory menyatakan investor lebih menyukai dividen dibandingkan dengan capital gain karena dividen bersifat lebih pasti, dengan demikian pembayaran dividen dapat meningkatkan nilai perusahaan. Namun pembayaran dividen kepada investor dapat mengurangi laba ditahan untuk 
operasional perusahaan sehingga dapat menghambat perkembangan perusahaan yang berakibat pada menurunnya nilai perusahaan.

Perusahaan manufaktur merupakan salah satu sektor yang terdaftar di BEI. Perusahaan manufaktur terbagi menjadi tiga subsektor yaitu, sektor industri dasar \& kimia, sektor aneka industri, dan sektor industri barang konsumsi. Perusahaan manufaktur sektor industri barang konsumsi memiliki kemampuan untuk berkembang sesuai dengan pertumbuhan penduduk karena memproduksi barangbarang yang menjadi kebutuhan pokok penduduk.

Tabel 1.

Rata-Rata Harga Saham Perusahaan Manufaktur yang Terdaftar di BEI Periode 2014-2016

\begin{tabular}{|c|c|c|c|c|c|c|c|}
\hline \multirow{3}{*}{ No } & \multirow{3}{*}{ Sub Sektor } & \multicolumn{6}{|c|}{ Harga Saham (Rp) } \\
\hline & & \multicolumn{2}{|c|}{2014} & \multicolumn{2}{|c|}{2015} & \multicolumn{2}{|c|}{2016} \\
\hline & & High & Low & High & Low & High & Low \\
\hline 1 & Industri Dasar \& Kimia & 556,25 & 513,00 & 444,44 & 396,11 & 490,27 & 455,41 \\
\hline 2 & Aneka Industri & 1336,37 & 1225,94 & 1251,34 & 1094,98 & 1325,38 & 1197,06 \\
\hline 3 & Barang Konsumsi & 2114,95 & 2009,18 & 2243,55 & 2081,63 & 2450,96 & 2299,16 \\
\hline & Rata-Rata & 1335,86 & 1249,37 & 1313,11 & 1190,91 & 1422,20 & 1317,21 \\
\hline
\end{tabular}

Sumber: data diolah, 2017

Berdasarkan Tabel diatas rata-rata harga saham tertinggi sektor industri dasar \& kimia mengalami penurunan pada tahun 2015 dan mengalami peningkatan kembali pada tahun 2016. Sektor aneka industri dengan juga mengalami penurunan pada harga saham tertinggi dan terendah pada tahun 2015 . Sektor ini kemudian mengalami peningkatan pada tahun 2016. Sektor industri barang konsumsi berada pada posisi pertama dalam rata-rata harga saham terendah dan tertinggi pada setiap periode dibandingkan dengan dua sektor 
lainnya. Rata-rata harga saham terendah dan tertinggi sektor barang konsumsi mengalami peningkatan setiap tahunnya. Rata-rata harga saham sektor industri barang konsumsi tertinggi dibandingkan dengan dua sektor lainnya yaitu sektor industri dasar \& kimia dan sektor aneka industri menunjukkan bahwa investor lebih tertarik berinvestasi pada perusahaan sektor industri barang konsumsi. Sektor ini juga memiliki harga saham diatas rata-rata harga saham perusahaan manufaktur setiap periodenya. Ketertarikan investor pada sektor ini yang menyebabkan meningkatkan harga saham perusahaan sektor industri barang konsumsi. Meningkatnya harga saham juga diikuti dengan meningkatnya nilai perusahaan, dengan demikian dapat dikatakan sektor industri barang konsumsi memiliki nilai perusahaan tertinggi dibandingkan dua sektor lainnya dalam perusahaan manufaktur.

Berdasarkan fenomena diatas, maka rumusan masalah penelitian yang akan diteliti yaitu apakah tax avoidance berpengaruh terhadap nilai perusahaan serta apakah kebijakan dividen mampu memoderasi pengaruh tax avoidance terhadap nilai perusahaan. Tujuan penelitiannya ialah diharapkan dapat memperoleh bukti empiris dan menjelaskan rumusan masalah diatas. Manfaat teoritis yang dapat diberikan yaitu sesuai dengan teori keagenan, teori sinyal dan teori bird in the hand serta memberikan tambahan referensi mengenai pengaruh tax avoidance terhadap nilai perusahaan dengan kebijakan dividen sebagai variabel moderasi. Manfaat praktis penelitian ini bagi perusahaan dan pemegang saham. 
Teori keagenan adalah kumpulan kontrak antara prinsipal dan agen dimana pihak prinsipal memberikan wewenang kepada agen untuk mengambil keputusan perusahaan atas nama prinsipal. Hubungan antara prinsipal dan agen seringkali menimbulkan konflik karena adanya perbedaan kepentingan. Perbedaan kepentingan tersebut dapat berupa keinginan prinsipal (pemegang saham) melakukan tax avoidance yang meningkatkan nilai perusahaan agar mendapatkan hasil investasi yang tinggi, sedangkan pihak agen (manajer perusahaan) hanya akan melakukan tax avoidance apabila hal tersebut memberi manfaat kepadanya. Perbedaan kepentingan lain contohnya dalam mengambil keputusan untuk laba yang diperoleh perusahaan setelah melakukan tax avoidance. Pihak prinsipal ingin laba tersebut dibagikan sebagai dividen, sedangkan pihak agen ingin laba tersebut digunakan sebagai operasional perusahaan. Konflik seperti ini disebut dengan agency problem (Kim, Nofsinger, dan Mohr, 2010).

Teori sinyal menekankan bagaimana perusahaan mampu menyampaikan prospek perusahaan di masa depan kepada investor. Menurut (Prasiwi, 2015) informasi adalah komponenterpenting bagi investor dan pelaku bisnis, karena informasi memberikancerminan untukkontinuitas perusahaan. Informasi yang lengkap, relevan, akurat dan tepat waktu sangat dibuthkan oleh investor di pasar modal sebagai pertimbangan dalam pengambilan keputusan. Dalam signaling theory, pembayaran investasi menjadi sinyal positif untuk perusahaan di masa mendatang, sehingga meningkatkan harga saham yang merupakan indikator nilai perusahaan (Jama'an, 2008). Prasiwi (2015) menyebutkan bagi pihak manajemen, praktik tax avoidance diharapkan dapat menjadi sinyal positif bagi pihak investor 
karena terjadi peningkatan nilai perusahaan. Karena pada dasarnya nilai perusahaan ditunjukkan oleh peningkatan harga saham perusahaan dari waktu ke waktu.

Teori bird in the hand menjelaskan keingingan investor atas pembayaran dividen yang tinggi. Gordon dan Lintner (1962-1963) menjelaskan bahwa investor menginginkan pembayaran dividen yang tinggi karena memperoleh dividen tinggi saat ini dianggap memiliki resiko lebih kecil daripada memperoleh capital gain di masa mendatang. Pembayaran dividen saat ini dianggap memiliki resiko lebih kecil karena jumlah dividen yang akan diperoleh memiliki sifat lebih pasti (predictable) sedangkan capital gain di masa mendatang bersifat belum pasti. Teori bird in the hand menunjukkan pembayaran dividen yang tinggi kepada investor akan meningkatkan harga saham perusahaan. Harga saham perusahaan yang meningkat menunjukkan nilai perusahaan juga meningkat. Berdasarkan beberapa penjelasan diatas maka peneliti merumuskan kerangka konseptual penelitian sebagai berikut:

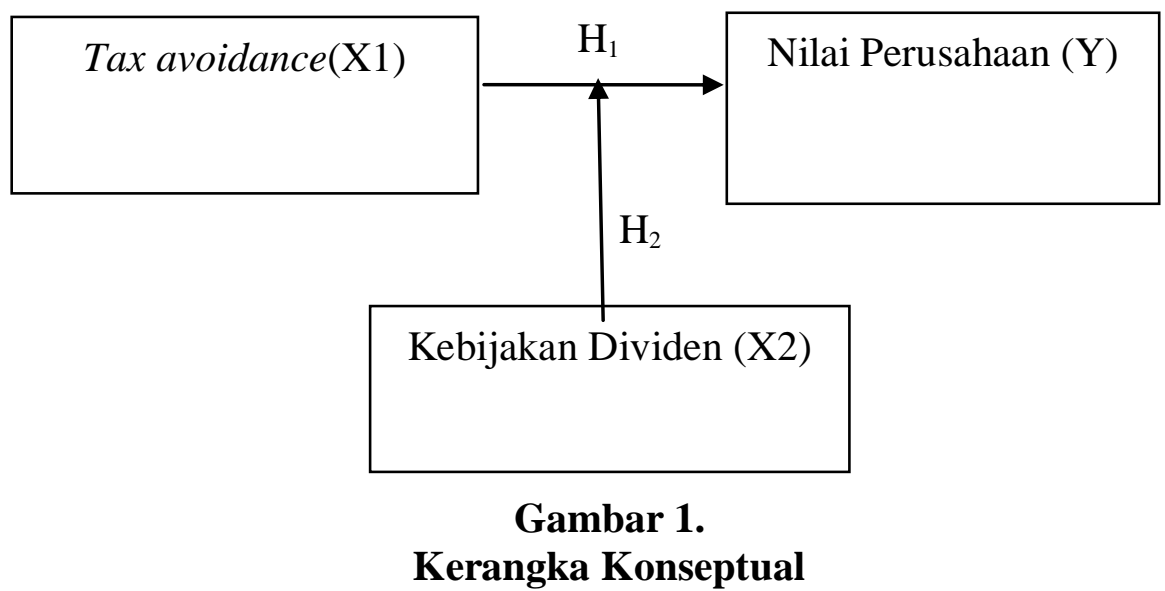


Terdapat beberapa cara yang dapat dilakukan perusahaan guna meningkatkan profitabilitas perusahaan, salah satunya dengan melakukan tax avoidance. Tax avoidance ialah upaya meminimalkan pembayaran pajak sehingga meningkatkan profitabilitas. Hanlon dan Slemrod (2009) mengatakan aktivitas agresivitas pajak dapat menaikkan atau menurunkan nilai perusahaan. Nilai perusahaan akan naik apabila agresivitas pajak dinilai sebagai upaya melakukan perencanaan pajak dan efisiensi pajak. Akan tetapi nilai perusahaan tersebut dapat turun jika dinilai sebagai ketidakpatuhan sehingga akan menurunkan nilai perusahaan.

Penelitian dari Ilmiani dan Sutrisno (2014) serta Ningtias (2015) memperoleh hasil tax avoidance berpengaruh negatif signifikan terhadap nilai perusahaan. Desai dan Dharmapala (2005) memperoleh hasil tax avoidancememengaruhi nilai perusahaan dengan arah positif pada perusahaan yang memilki corporate governance yang baik. Herdiyanto dan Ardiyanto (2015) juga menunjukkan bahwa tax avoidance berpengaruh positif terhadap nilai perusahaan.Tax avoidance diproksikan dengan tarif pajak efektif (effective tax rates) dimana perusahaan yang melakukan penghindaran pajak memiliki tarif pajak efektif yang lebih kecil.

Pembagian laba dalam bentuk dividen meningkatkan kesejahteraan pemegang saham yang akan meningkatkan nilai saham perusahan. Teori bird in the hand jugamenjelaskan besarnya dividen yang dibagikan kepada para pemegang saham akan meningkatkan harga saham, selain itu hal ini juga menjadi daya tarik bagi pemegang saham yang lain sehingga meningkatkan nilai 
perusahaan. Penelitian yang dilakukan Sugiarto (2011); Fenandar (2012); Putra dan Lestari (2016) yang memperoleh hasil kebijakan dividen berpengaruh positif dan signifikan terhadap nilai perusahaan sedangkan penelitian Abidin, dkk (2013) serta Faridah dan Kurnia (2016) yang menyatakan kebijakan dividen berpengaruh negatif dan signifikan terhadap nilai perusahaan. Berdasarkan penjelasan dan penjabaran diatas, maka hipotesis yang dapat ditarik yakni tax avoidance berpengaruh terhadap nilai perusahaan $\left(\mathrm{H}_{1}\right)$ serta kebijakan dividen memoderasi pengaruh tax avoidance terhadap nilai perusahaan $\left(\mathrm{H}_{2}\right)$.

\section{METODE PENELITIAN}

Jenis data yakni data kuantitatif tahun 2014-2016 yang tercatat oleh BEI bersumber pada perusahaanmanufaktur sektor industri barang konsumsi (www.idx.co.id), dengan purposive samplingsebagaiteknik penentuan sampel. Terdapat beberapa syarat, yaitu perusahaan yang terdaftar selama periode penelitian, perusahaan yang menyajikan laporan keuangan yang telah diaudit dan menyajikan informasi yang dibutuhkan dalam menghitung variabel penelitian, serta perusahaan yang memiliki nilai pretax income positif selama periode penelitian. Populasi dalam penelitian ini adalah 38 perusahaan manfaktur sektor industri barang konsumsi. Terdapat 25 perusahaan yang tidak memenuhi syarat dengan rincian sebagai berikut: 1 perusahaan terdaftar setelah tahun 2014 dan 24 perusahaan yang tidak menyajikan informasi yang lengkap untuk menghitung variabel yang dibutuhkan sehingga sampel dalam penelitian ini berjumlah 13 perusahaan manufaktur sektor industri barang konsumsi dikalikan 3 periode pengamatan maka total sampelnya adalah 39 perusahaan manufaktur sektor 
industri barang konsumsi. Variabel terikat dalam penelitian ini adalah nilai perusahaan.Nilai perusahaan adalah pandangan investor terhadap perusahaan yang dilihat melalui harga sahamnya (Sujoko dan Subiantoro, 2007). Nilai perusahaan diukur menggunakan Tobin's Q. James Tobin (1967) mengembangkan Tobin's Q dan dinilai dapat memberikan informasi yang paling baik, karena rasio ini dapat menjelaskan berbagai fenomena yang ada dalam kegiatan perusahaan seperti terjadinya perbedaan crossectional dalam pengambilan keputusan investasi (Simarmata, 2014). Nilai Tobin's Q yang rendah (antara 0 dan 1) mengindikasikan biaya penggantian aktiva yang lebih besar daripada nilai perusahaan tersebut. Semakin besar nilai Tobin's Q maka semakin tinggi nilai perusahaan dan mengindikasikan perusahaan memiliki prospek yang baik. Nilai Tobin's Q diatas satu mengindikasikan perusahaan memiliki aset tidak berwujud karena nilai perusahaan lebih besar dari biaya ganti aktiva perusahaan. Aset tidak berwujud itu dapat berupa intellectual capital. Tobin's Q dapat dirumuskan sebagai berikut:

Tobin's $\mathrm{Q}=\frac{M V E+D}{B V E+D}$

Keterangan:

Tobin's Q = Nilaiperusahaan.

MVE = Nilai pasar ekuitas (Market Value ofEquity), merupakan perkalian antara nilai pasar saham diakhir periode dengan jumlah saham yang beredar diakhir periode.

BVE = Nilai Buku Ekuitas (Book Value of Equity), merupakan selisih antara total aset perusahaan dengan total kewajiban.

D = Nilai buku dari total utang perusahaan diakhir periode.

Varibel bebas dalam penelitian ini adalah tax avoidance.Penghindaran pajak (tax avoidance) adalah cara menekan pembayaran pajak yang masih dalam batas ketentuan peraturan perundang-undangan perpajakan(Zain, 2008). 
Penghindaran pajak merupakan hal yang legal karena tidak melanggar peraturan perundang-undangan perpajakan yang berlaku dan hanya menggunakan hal-hal yang ada dalam peraturan perundang-undangan tersebut. Penghindaran pajak merupakan upaya meminimalkan kewajiban pajak (Dyreng, et al, 2008). Penghindaran pajak perusahaan dipercaya mencerminkan transfer kekayaan dari pemerintah kepada korporasi dan berpengaruh pada meningkatnya nilai perusahaan (Chen et al., 2013). Dalam definisi luas, penghindaran pajak merupakan serangkaian taktik perencanaan pajak (tax planning), karena secara ekonomis berusaha untuk meningkatkan laba setelah pajak (after tax return).Tax avoidance diukur menggunakan Effective Tax Rates (ETR). Effective Tax Rates (ETR) yang rendah mengindikasikan aktivitas tax avoidance yang tinggi. Effective Tax Rates (ETR) dirumuskan sebagai berikut:

$\mathrm{ETR}=\frac{\text { Total Tax Expense }}{\text { Pre Tax Income }}$

Keterangan:

ETR

Total Tax Expenses

= Effective Tax Rate (Tarif Pajak Efektif).

Pre Tax Income

$=$ Total Beban pajak.

$=$ Laba sebelum pajak.

Variabel moderasi dalam penelitian ini adalah kebijakan dividen yaitu keputusan keuangan perusahaan apakah laba akan dibagikan sebagai dividen atau ditahan dalam bentuk laba ditahan (Agus Sartono 2014: 281). Menurut teori signaling hypothesis meningkatnya pembayaran dividen menunjukkan semakin tinggi tingkat pengembalian kepada investor yang diikuti dengan meningkatnya harga saham. Hal ini turut menaikkan nilai perusahaan terkait dengan tujuan dari perusahaan itu sendiri, yaitu untuk memaksimalkan kemakmuran pemegang 
saham (Gultom, 2008). Kebijakan dividen diukur menggunakandividend payout ratio (DPR) yang dirumuskan sebagai berikut:

$\mathrm{DPR}=\frac{\mathrm{DPS}}{\mathrm{EPS}}$

Keterangan:

DPS = dividend per share

EPS = earning per share

\section{HASIL DAN PEMBAHASAN}

Pembahasan pertama akan dijelaskan terlebih dahulu mengenai pemeriksaan statistik deskriptif tentangbesaranmean atau rata-rata, data yang memiliki nilai rendah (minimum), data yang memiliki nilai tinggi (maksimum), dan standard deviation. Setelah itu akan dijelaskan mengenai hasil uji asumsi klasik yang terdiri dari uji normalitas, uji autokorelasi, uji heteroskedastisitas. Selanjutnya penjelasan mengenai hasil analisis MRA yang dilanjutkan dengan penjelasan hasil uji koefisien determinasi, hasil uji kelayakan model, dan yang tekahir hasil uji parsial.

Tabel 2.

Statistik Deskriptif Variabel Penelitian

\begin{tabular}{|c|c|c|c|c|c|}
\hline & $\mathbf{N}$ & Minimum & Maximum & Mean & Std. Deviation \\
\hline Tobin's Q & 39 & .16 & 18.64 & 5.1395 & 5.17356 \\
\hline ETR & 39 & .066 & .349 & .25412 & .042930 \\
\hline DPR & 39 & .68 & 145.92 & 53.8192 & 28.86494 \\
\hline
\end{tabular}

Valid N (listwise) 39

Sumber: Data Diolah (2017)

Berdasarkan data diatas, besaran nilai mean Tobin's Q yaitu 5.1395, nilai minimum yakni 0.16 , nilai maksimum ialah 18.64 , dan standar deviasi bernilai 5.17356. ETR mempunyai nilai mean sejumlah0.25412. Nilai rata-rata ETR 0,25412 menunjukkan adanya indikasi perusahaan yang tidak melakukan 
penghindaran pajak dengan nilai rata-rata 0,25412. Nilai minimum ETR sejumlah 0.066, nilai maksimum sejumlah 0.349 , dan nilai standar deviasi sejumlah 0.042930. Nilai mean DPR yaitu 53.8192, nilai minimum yaitu0.68, nilai maksimum yaitu 145.92, dan nilai standar deviasi yaitu 28.86494 .

Tabel 3.

Hasil Uji Normalitas

\begin{tabular}{|c|c|c|}
\hline & & $\begin{array}{c}\text { Unstandardized } \\
\text { Residual } \\
\end{array}$ \\
\hline $\mathrm{N}$ & & 39 \\
\hline \multirow{2}{*}{ Normal Parameters ${ }^{\mathrm{a}, \mathrm{b}}$} & Mean & .0000000 \\
\hline & Std. Deviation & 1.85671822 \\
\hline \multirow[t]{3}{*}{ Most Extreme Differences } & Absolute & .149 \\
\hline & Positive & .149 \\
\hline & Negative & -.119 \\
\hline Kolmogorov-Smirnov Z & & .933 \\
\hline Asymp. Sig. (2-tailed) & & .348 \\
\hline
\end{tabular}

Uji normalitas bertujuan untuk menguji apakah dalam model regresimemiliki distribusi normal atau tidak. Untuk mendeteksi normalitas data digunakan Kolmogorov-Smirnov. Pada Tabel 2 terlihat nilai asymp. sig. (2-tailed) dari hasil uji normalitas $0.348<0.05$ sehingga dapat diambil kesimpulan data berdistribusi normal.

Tabel 4.

Hasil Uji Autokorelasi

\begin{tabular}{lrrrrr}
\hline Model & & & & & \\
& R & R Square & Adjusted R Square & Std. Error of the Estimate & Durbin-Watson \\
\hline 1 & $.993^{\mathrm{a}}$ & .871 & .860 & 1.93466 & 1.735 \\
\multicolumn{7}{l}{ Sumber: Data Diolah, 2017}
\end{tabular}

Uji autokorelasi dilakukan untuk melacak adanya korelasi data dari tahun $\mathrm{t}$ dengan tahun t-1 (sebelumnya). Uji autokorelasi menggunakan Uji DurbinWatson (DW-test) atau d statistik. Tabel 3 menunjukkan nilai Durbin-Watson 
sebesar 1.735. Jumlah data pada penelitian ini adalah $n=39$ dan $\mathrm{k}=1$ dengan taraf signifikansi 5\% sehingga diperoleh $\mathrm{d}_{\mathrm{L}}=1.4347$ dan $\mathrm{d}_{\mathrm{U}}=1.5396$ sehingga nilai 4$\mathrm{d}_{\mathrm{U}}=2.4604$. Dengan demikian hasil uji autokorelasi dengan kriteria $\mathrm{d}_{\mathrm{U}}<\mathrm{d}_{\mathrm{W}}<(4-$ $\left.\mathrm{d}_{\mathrm{U}}\right)$ adalah $1.4347<1.735<2.6404$, maka dapat disimpulkan bahwa model regresi yang dibuat tidak mengandung gejala autokorelasi.

Tabel 5.

Hasil Uji Heterokedastisitas

\begin{tabular}{|c|c|c|c|c|c|c|}
\hline \multirow{2}{*}{\multicolumn{2}{|c|}{ Model }} & \multicolumn{2}{|c|}{$\begin{array}{l}\text { Unstandardized } \\
\text { Coefficients }\end{array}$} & \multirow{2}{*}{$\begin{array}{c}\text { Standardized } \\
\text { Coefficients } \\
\text { Beta } \\
\end{array}$} & \multirow[b]{2}{*}{$\mathbf{t}$} & \multirow[b]{2}{*}{ Sig. } \\
\hline & & B & Std. Error & & & \\
\hline \multirow[t]{4}{*}{1} & (Constant) & .021 & .604 & & .035 & .972 \\
\hline & ETR & 1.614 & 2.052 & .405 & .786 & .437 \\
\hline & DPR & .010 & .013 & .556 & .747 & .460 \\
\hline & Interaksi ETR dan DPR & -.030 & .046 & -.550 & -.657 & .516 \\
\hline
\end{tabular}

Sumber: Data Diolah, 2017

Uji heteroskedastisitas dilakukan untuk menguji model regresi apakah terjadi ketidaksamaan varian dari residual satu pengamatan ke pengamatan lain. Uji heteroskedastisitas pada penelitian ini menggunakan uji GlejserTabel 4 menunjukkan bahwa nilai sigifikansi dari variabel tax avoidance, kebijakan dividen dan interaksi tax avoidance dengan kebijakan dividen masing-masing sebesar $0.437,0.460$ dan 0.516 . Nilai tersebut lebih besar dari 0.05 dengan demikian model yang dibuat tidak mengandung gejala heteroskedastisitas.

Tabel 6.

Hasil Uji Moderated Regression Analysis (MRA)

\begin{tabular}{llrrrrr}
\hline Model & \multicolumn{7}{c}{$\begin{array}{c}\text { Standardized } \\
\text { Unstandardized Coefficients } \\
\end{array}$} & \multicolumn{1}{c}{$\begin{array}{c}\text { Coefficients } \\
\text { Beta }\end{array}$} & \multicolumn{1}{c}{ T } & Sig. \\
\hline 1 & (Constant) & 3.968 & .719 & & 5.521 & .000 \\
& ETR & 1.450 & .335 & .310 & 4.322 & .000 \\
& DPR & .011 & .001 & .971 & 10.335 & .000 \\
& Interaksi ETR dan DPR & -.295 & .056 & -.444 & -5.279 & .000 \\
\hline
\end{tabular}


Tabel 6.

Hasil Uji Moderated Regression Analysis (MRA)

\begin{tabular}{|c|c|c|c|c|c|c|}
\hline \multirow{3}{*}{\multicolumn{2}{|c|}{ Model }} & \multicolumn{5}{|c|}{ Standardized } \\
\hline & & \multicolumn{2}{|c|}{ Unstandardized Coefficients } & \multicolumn{3}{|l|}{ Coefficients } \\
\hline & & & 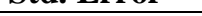 & & & Sig. \\
\hline \multirow[t]{4}{*}{1} & (Constant) & 3.968 & .719 & & 5.521 & .000 \\
\hline & ETR & 1.450 & .335 & .310 & 4.322 & .000 \\
\hline & DPR & .011 & .001 & .971 & 10.335 & .000 \\
\hline & Interaksi ETR dan DPR & -.295 & .056 & -.444 & -5.279 & .000 \\
\hline
\end{tabular}

Berdasarkan hasil yang di atas, diperoleh persamaan regresi sebagai berikut:

Tobin's Q $=3,968+1,450$ ETR + 0,011 DPR $-0,295$ ETR.DPR

Koefisien regresi dari ETR memiliki koefisien 1.450 yang berarti ETR berpengaruh positif terhadap nilai perusahaan. Setiap kenaikan 1\% ETR akan meningkatkan nilai perusahaan sebesar $1.450 \%$ dengan asumsi variabel lain konstan. Koefisien interaksi ETR dan DPR memiliki nilai -0.295 berarti ETR dan DPR berhubungan negatif. Setiap kenaikan ETR sebesar $1 \%$ akan menurunkan DPR sebesar $0.295 \%$ dengan asumsi variabel lain konstan.

Tabel 7.

Hasil Uji Koefisien Determinasi

$S$

\begin{tabular}{lrrrr}
\hline Model & R & R Square & Adjusted R Square & Std. Error of the Estimate \\
\hline 1 & $.993^{\mathrm{a}}$ & .871 & .860 & 1.93466
\end{tabular}

Sumber: Data Diolah, 2017

$R$ Squaredigunakan dalam melihat seberapa kuat variabel terikat dipengaruhi variabel bebas dan variabel moderasi. Penelitian ini menggunakan adjusted $R$ square untuk mengatasi bias $R$ square. Adjusted $R$ square memperlihatkan angka senilai 0.860 yang berarti bahwa $86 \%$ persen variasi dari variabel dependen, yakni nilai perusahaan dipengaruhi oleh variasi dari variabel independen, yakni tax avoidance, kebijakan dividen, serta interaksi antara tax 
avoidance dengan kebijakan dividen, sedangkan $14 \%$ persen sisanya diakibatkan dari variabel lain yang tidak dimasukkan dalam model regresi.

Tabel 8.

Hasil Uji Kelayakan Model (Uji F)

\begin{tabular}{llrrrrr}
\hline Model & & Sum of Squares & Df & Mean Square & \multicolumn{1}{l}{ F } & \multicolumn{1}{c}{ Sig. } \\
\hline 1 & Regression & 886.098 & 3 & 295.366 & 78.914 & $.000^{\mathrm{a}}$ \\
& Residual & 131.001 & 35 & 3.743 & & \\
& Total & 1017.099 & 38 & & & \\
\hline
\end{tabular}

Sumber: Data Diolah, 2017

Hasil uji F model regresi diperoleh nilai signifikansi senilai $0.000<0.05$ dengan $\mathrm{F}$ hitung 78.914 maka tax avoidance, kebijakan dividen, serta interaksi antara tax avoidance dengan kebijakan dividen memengaruhi nilai perusahaan secara serempak. Sehingga model yang digunakan dikatakan layak.

\section{Tabel 9.}

Hasil Uji Parsial (Uji t)

\begin{tabular}{|c|c|c|c|c|c|c|}
\hline \multicolumn{2}{|c|}{ Model } & \multicolumn{2}{|c|}{$\begin{array}{l}\text { Unstandardized } \\
\text { Coefficients }\end{array}$} & \multirow{2}{*}{$\begin{array}{c}\text { Standardized } \\
\text { Coefficients } \\
\text { Beta } \\
\end{array}$} & \multirow[b]{2}{*}{$\mathbf{T}$} & \multirow[b]{2}{*}{ Sig. } \\
\hline & & B & Std. Error & & & \\
\hline \multirow[t]{4}{*}{1} & (Constant) & 3.968 & .719 & & 5.521 & .000 \\
\hline & ETR & 1.450 & .335 & .310 & 4.322 & .000 \\
\hline & DPR & .011 & .001 & 971 & 10.335 & . 000 \\
\hline & Interaksi ETR dan DPR & -.295 & .056 & -.444 & -5.279 & .000 \\
\hline
\end{tabular}

Sumber: Data Diolah, 2017

Hipotesis pertama yang diajukan yakni tax avoidance berpengaruh terhadap nilai perusahaan diterima sesuai hasil uji regresi yang telah dilaksanakan. Signifikansi yang memperoleh angka $0.000<0.025$ sehingga hipotesis pertama diterima. Koefisien regresi ETR adalah sebesar 1.450. Tax avoidance diproksikan dengan ETR sehingga hasil ini menunjukkan ETR berpengaruh positif terhadap nilai perusahaan. Hasil ini menunjukkan semakin rendah ETR suatu perusahaan maka semakin rendah pula nilai perusahaan. ETR yang rendah mengindikasikan 
adanya penghindaran pajak yang tinggi sehingga dapat disimpulkan tax avoidance berpengaruh negatif terhadap nilai perusahaan.

Bagi perusahaan aktivitas tax avoidance dapat menurunkan nilai perusahaan karena aktivitas ini dapat menimbulkan konflik agency antara manajer dengan pemegang saham. Konflik agency ini muncul karena adanya perbedaan kepentingan antara manajer dan pemegang saham dimana kedua belah pihak hanya mengutamakan kepentingan pribadi saja. Hal ini dapat menyebabkan adanya sifat opportunistic manajer dalam upaya tax avoidance dengan merugikan investor. Hal inilah yang berpengaruh terhadap menurunnya nilai perusahaan. Aktivitas tax avoidance yang dilakukan perusahaan dianggap sebagai bentuk ketidakpatuhan perusahaan terhadap peraturan perpajakan yang berlaku. Ketidakpatuhan perusahaan terhadap peraturan perpajakan menyebabkan perusahaan dinilai buruk oleh investor. Ketika suatu perusahaan memiliki citra yang buruk maka investor akan enggan untuk berinvestasi di perusahaan tersebut.

Selain itu, bagi investor aktivitas tax avoidance dapat menyesatkan investor karena perusahaan menyajikan informasi keuangan yang telah dimanipulasi. Hal ini menyebabkan investor kehilangan kepercayaan untuk berinvestasi di perusahaan tersebut yang berakibat pada menurunnya nilai perusahaan.

Hasil ini sejalan dengan penelitian dari Chen et. al., (2013) yang menemukan bahwa tax avoidance berpengaruh negatif terhadap nilai perusahaan karena dapat menimbulkan biaya keagenan. Pengaruh negatif tersebut diperlemah dengan adanya transparansi. Ilmiani dan Sutrisno (2014); Ningtias (2015); 
Ampriyanti dan Lely (2016) serta Azhar (2017) juga memperoleh hasil tax avoidance berpengaruh negatif signifikan terhadap nilai perusahaan.

Hipotesis selanjutnya, yakni kebijakan dividen memoderasi pengaruh tax avoidance terhadap nilai perusahaan dapat diterima. Signifikansi interaksi ETR dan DPR $0.000<0.025$ sehingga hipotesis kedua diterima. Koefisien regresi interaksi ETR dan DPR adalah sebesar -0.295. Hasil ini menunjukkan bahwa kebijakan dividen memoderasi pengaruh tax avoidance terhadap nilai perusahaan. Nilai koefisien regresi $-0,295$ menunjukkan bahwa kebijakan dividen memperlemah pengaruh negatif tax avoidance terhadap nilai perusahaan. Hal ini berarti pembayaran dividen dapat menjadi sinyal positif bagi investor. Penurunan nilai perusahaan yang terjadi akibat adanya aktivitas tax avoidance dapat diatasi dengan pembayaran dividen kepada investor. Teori bird in the hand menyatakan investor lebih menyukai dividen dibandingkan dengan capital gain karena dividen besifat lebih pasti. Berdasarkan teori tersebut, pembayaran dividen mampu meningkatkan nilai perusahaan sehingga mengatasi penurunan nilai perusahaan akibat adanya tax avoidance.

Selain itu, bagi perusahaan tingkat pembayaran dividen yang tinggi mampu menjadi daya tarik bagi investor lain untuk berinvestasi di suatu perusahaan. Hal ini dikarenakan perusahaan yang melakukan pembayaran dividen menunjukkan tingkat kesejahteraan pemegang saham dan mengindikasikan perusahaan memiliki kinerja yang baik sehingga dapat meningkatkan nilai perusahaan. 
Hasil ini sejalan dengan Mardiyati dkk (2012); Lestari dkk (2012); dan Herawati (2013) yang menemukan kebijakan dividen berpengaruh positif namun tidak signifikan terhadap nilai perusahaan, sedangkan penelitian yang dilakukan Raharja (2014) menyatakan kebijakan dividen berpengaruh signifikan terhadap nilai perusahaan. Hasil penelitian Sugiarto (2011); Fenandar (2012); Putra dan Lestari (2016) memperoleh hasil kebijakan dividen berpengaruh positif dan signifikan terhadap nilai perusahaan. Hasil penelitian tersebut dapat mendukung hasil yang telah diperoleh karena dalam penelitian tersebut kebijakan dividen dapat meningkatkan nilai perusahaan, dengan kata lain kebijakan dividen mampu memperlemah pengaruh negatif tax avoidance terhadap nilai perusahaan.

\section{SIMPULAN}

Berdasarkan hasil penelitian yang diperoleh melalui pengujian statistik serta pembahasan seperti yang telah diuraikan maka dapat disimpulkan bahwa: ETR berpengaruh positif terhadap nilai perusahaan. ETR yang rendah mengindikasikan tax avoidance yang tinggi berpengaruh terhadap menurunnya nilai perusahaan. Hasil ini menunjukkan bahwa semakin tinggi aktivitas tax avoidance suatu perusahaan dapat menurunkan nilai perusahaan. Aktivitas tax avoidance yang dilakukan perusahaan menyebabkan perusahan memiliki citra yang buruk karena dianggap tidak patuh pada ketentuan perpajakan dan menyesatkan investor dengan menyajikan laporan keuangan yang tidak sebenarnya.Kebijakan dividen memperlemah pengaruh negatif antara tax avoidance dengan nilai perusahaan. Hasil ini menunjukkan bahwa ketika laba dari aktivitas tax avoidance dibagikan sebagai dividen maka nilai perusahaan akan naik karena pembayaran dividen 
kepada pemegang saham dapat meningkatkan kesejahteraan pemegang saham. Selain itu, pembayarandividen menunjukkan perusahaan memiliki kinerja yang baik sehingga menarik investor baru untuk berinvestasi di perusahaan tersebut.

Adapun saran yang dapat diberikan berdasarkan uraian tersebut yakni perusahaan sebaiknya mengambil langkah yang tepat dalam rangka meningkatkan nilai perusahaan, salah satunya dengan pembayaran dividen karena pembayaran dividen dapat meningkatkan kesejahteraan pemegang saham dan menjadi sinyal positif bagi investor lain untuk melakukan investasi di perusahaan tersebut yang berimplikasi pada meningkatnya nilai perusahaan.Investor dalam melakukan investasi sebaiknya menganalisis Effective Tax Rates perusahaan yaitu perbandingan antara total beban pajak dengan laba sebelum pajak dimana Effective Tax Rates yang rendah menunjukkan tingginya aktivitas tax avoidance yang berakibat pada menurunnya nilai perusahaan.

Implikasi dari penelitian ini terdiri dari dua, yaitu implikasi teoritis dan implikasi praktis. Implikasi teoritis hasil penelitian menunjukkan bahwa ETR berpengaruh positif terhadap nilai perusahaan dengan kata lain tax avoidance berpengaruh negatif terhadap nilai perusahaan dan kebijakan dividen memperlemah pengaruh negatif tax avoidance terhadap nilai perusahaan. Berdasarkan hasil penelitian tersebut, sejalan dengan teori agensi dimana kegiatantax avoidance yang dilakukan oleh perusahaan dapat menimbulkan konflik antara manajer dan pemegang saham karena adanya perbedaan kepentingan sehingga berakibat pada menurunnya nilai perusahaan. Hasil penelitian ini juga sesuai dengan bird in the hand theory yang menyatakan 
investor lebih menyukai dividen dibandingkan dengan capital gain sehingga pembagian dividen meningkatkan nilai perusahaan. Implikasi praktis bagi perusahaan hasil penelitian ini menunjukkan bahwa tax avoidance memengaruhi nilai perusahaan dan kebijakan dividen mampu memengaruhi hubungan tax avoidance dan nilai perusahaan. Tax avoidance merupakan upaya mengurangi beban perusahaan yang dapat menurunkan nilai perusahaan. Pembayaran dividen kepada investor memperlemah hubungan negatif tax avoidance terhadap nilai perusahaan karena pembayaran dividen meningkatkan kesejahteraan pemegang saham. Bagi pemegang saham hasil penelitian diatas, maka dapat menjadi pertimbangan bagi pemegang saham untuk mengambil keputusan investasi dengan melihat prospek perusahaan di masa mendatang tidak hanya terpaku pada performa perusahaan di satu periode saja.

\section{REFERENSI}

Agus Sartono. (2014). Manajemen Keuangan, Teori dan Aplikasi. Edisi Empat. Yogyakarta: BPFE.

Ampriyanti, Ni Made dan Aryani, Ni Kt Lely. 2016. Pengaruh Tax Avoidance terhadap Nilai Perusahaan dengan Karakter Eksekutif sebagai Variabel Pemoderasi. E-Jurnal Akuntansi Universitas Udayana, 16(3), hal: 22312259.

Amstrong, Christian, L. Blonin, Jennifer, D. Jagolinzer, Alan and Larcker, David. 2012. Corporate Governance, Incentives, and Tax Avoidance. Journal of Empirical Finance, 18.

Chen, Xudong. dkk. 2013. Tax avoidance and Firm Value: Evidence from China. Nankai Business Review, 5.

Desai, Mihir. A and Dhammika Dharmapala, 2005, Corporate Tax avoidance and Firm Value. National Bureau of Economic Research, 11241.

Dyreng et al. 2008. Long Run Corporate Tax avoidance. The Accounting Review, 83(1), pp: 61-82. 
Faridah, Nur dan Kurnia. 2016. Pengaruh Keputusan Investasi, Pendanaan, Kebijakan Dividen, Tingkat Suku Bunga terhadap Nilai Perusahaan. Jurnal Ilmu dan Riset Akuntansi, 6(2), hal:1-16.

Fenandar, Gany Ibrahim dan Surya Raharja. 2012. Pengaruh Keputusan Investasi, Keputusan Pendanaan dan Kebijakan Dividen terhadap Nilai Perusahaan. Journal of Accounting, 1 (2), hal:1-10.

Frank, M.M., Lynch, L.J., \& Rego, S.O. 2009. Tax Reporting Aggressiveness and Its Relation to Aggressive Financial Reporting. The Accounting Review, 84(2), pp: 467-496.

Gultom dan Syarif, 2008. Pengaruh Kebijakan Leverage, Kebijakan Deviden dan Earning per Share terhadap Nilai Perusahaan pada perusahaan Manufaktur yang terdaftar di Bursa Efek Indonesia. Jurnal Akuntansi USU.

Hanlon, M., dan Slemrod, J.B. 2009. What Does Tax Aggressiveness Signal? Evidence From Stock Price Reactions To News About Tax Shelter Involvement. Journal of Public Economic, 93 (1-2),pp:126-141.

Hanlon, Michelle dan Shane Heitzman (2010), A Review of Tax Research, Journal of Accounting and Economics 50, pp:127 - 178.

Herawati, Titin. 2013. Pengaruh Kebijakan Dividen, Kebijakan Hutang, dan Profitabilitas terhadap Nilai Perusahaan. Jurnal Manajemen, 2(2), pp:1-18.

Herdiyanto, Dedy Ghozim dan Ardiyanto, Moh. Didik. 2015. Pengaruh Tax Avoidance terhadap Nilai Perusahaan. Jurnal Akuntansi Fakultas Ekonimika dan Bisnis Universitas Diponegoro, 4(3), hal: 1-10.

Hoque, Md. Jahirul, Mohammad Z.H. Bhuiyan, dan Afzal Ahmad. 2011. Tax Evasion and Avoidance Crimes - A Study on Some Corporate Firms of Bangladesh. Eastern University and International Islamic University Chittagong Working Paper.

Ilmiani, Amalia dan Catur Ragil Sutrisno. 2014. Pengaruh Tax avoidance terhadap Nilai Perusahaan dengan Transparansi Perusahaan Sebagai Variabel Moderating. Jurnal Ekonomi dan Bisnis, 14(1), hal:30-39.

Jama'an.2008 Pengaruh Mekanisme Corporate Governance, dan Kualitas Kantor Akuntan Publik Terhadap Integritas Informasi Laporan Keuangan (Studi Kasus Perusahaan Publik yang Listing di BEJ). Skripsi. Fakultas Ekonomika dan Bisnis Universitas Diponegoro.

Kim, K.A., Nofsinger J.R., \& Mohr, D.J. (2010). Corporate governance (3rd ed.). United Stated: Prentice Hall. 
Mardiyati, Umi., Gatot Nazir Ahmad, dan Ria Putri. 2012. Pengaruh Kebijakan Dividen, Kebijakan Hutang dan Profitabilitas terhadap Nilai Perusahaan Manufaktur yang Terdaftar di Bursa Efek Indonesia (BEI) periode 20052010. Jurnal Riset Manajemen Sains Indonesia (JRMSI), 3 (1), hal:1-17.

Minnick, Kristina and Tracy, Noga. 2010. Do Corporate Governance Characteristics Influence Tax Management?. Journal of Corporate Finance, 16, pp:703-718.

Ningtias, Putri Ayu. 2015. Pengaruh Tax Avoidance terhadap Nilai Perusahaan dengan Efektifitas Komite Audit sebagai Variabel Moderating. Skripsi. Fakultas Ekonomi dan Bisnis Universitas Islam Negeri Syarif Hidayatullah.

Pradnyana, Ida Bagus Gede Putra dan Naniek Noviari. 2017. Pengaruh Perencanaan Pajak terhadap Nilai Perusahaan dengan Transparansi Perusahaan sebagai Variabel Moderasi. Jurnal Akuntansi, 18(2), hal:13981425.

Prasiwi, Kristantina Wahyu. 2015. Pengaruh Penghindaran Pajak terhadap Nilai Perusahaan: Transparansi Informasi sebagai Variabel Pemoderasi. Skripsi. Fakultas Ekonomika dan Bisnis Universitas Diponegoro.

Putra, AA Ngurah Dharma Adi dan Lestari, Putu ViVi. 2016. Pengaruh Kebijakan Dividen, Likuiditas, Profitabilitas, dan Ukuran Perusahaan terhadap Nilai Perusahaan. E-Jurnal Manajemen Unud, 5(7), hal:40444070 .

Raharja, Athian. 2014. Pengaruh Kebijakan Hutang dan Kebijakan Dividen terhadap Nilai Perusahaan (Studi Pada Perusahaan Manufaktur yang Terdaftar di Bursa Efek Indonesia Periode 2010-2012). Skripsi. Fakultas Ekonomi Universitas Widyatama.

Sugiarto, Melanie. 2011. Pengaruh Struktur Kepemilikan dan Kebijakan Dividen terhadap Nilai Perusahaan Dengan Kebijakan.Hutang Sebagai Intervening. Jurnal Akuntansi Kontemporer, 3 (1), hal:1-25.

Sujoko dan Ugy Soebiantoro. 2007. Pengaruh Struktur Kepemilikan Saham, Leverage, Faktor Intern dan Faktor Ekstern terhadap Nilai Perusahaan. Jurnal Manajemen dan Kewirausahaan, 9(1).

Tarihoran, Anita. 2016. Pengaruh Penghindaran Pajak dan Leverage terhadap Nilai Perusahaan dengan Transparansi Perusahaan sebagai Variabel Moderasi. Jurnal Wira Ekonomi Mikroskill, 6(2), hal:149-164

Wahab, Abdul N.S, dan Holland, Kevin. 2012. Tax Planning, Corporate Governance dan Equity Value. The British Accounting Review, (44), pp:111- 124. 
Lina Apsari dan Putu Ery Setiawan. Pengaruh ...

Zain, Mohammad. 2008. Manajemen Perpajakan. Jakarta: Salemba Empat. 